島倉洋造

\title{
A Case Report of Full Mouth Reconstruction for Patient with Severe Periodontitis
}

Yōzō Shimakura

\begin{abstract}
Dental science has remarkable progress in recent years. There are new discoveries in basic research study, for example genetics and molecular biology. In clinical new techniques that anyone had not expected in the past, for example GTR, Implant and Auto tooth transplantation has consensus at present. However, application of the technique to patient in clinical is more difficult. This full mouth reconstruction case applied various techniques, for example orthodontic treatment, auto tooth transplantation and prosthodontic treatment, to severe periodontitis patient will be reported.

近年の歯科の進歩は著しく, 目を見張るものがある。基礎研究では遺伝子, 分子生物学 では次々と新たな発見があり, 臨床でも，再生療法，インプラント，自家歯牙移植といっ た過去には考えられなかった手法もコンセンサスが得られてきた。そのような先人たちの 遺産を臨床に応用していくわけだが，実際行うのは困難がつきまとう。今回は重度歯周病 患者に対して, 全顎矯正，自家歯牙移植，そして補綴治療により咬合再構成した症例を報 告したい.
\end{abstract}

Key words : 自家歯牙移植 auto tooth transplantation, 矯正治療 orthodontic treatment, 咬合再構成 full mouth reconstruction

\section{症例}

患者：53歳 男性 会社員 非契煙者

初診：1995 年 8 月 31 日

主訴：左下奥歯が痛くて噛めない

既往歴：特記事項なし

歯式：8 \begin{tabular}{llllll|lllllll}
8 & 6 & 5 & 3 & 2 & 1 & 1 & 2 & 3 & 4 & 5 & 6 & 7 \\
\hline 7 & 5 & 4 & 3 & 2 & 1
\end{tabular}

現症： 7 の咬合痛にて来院，過去に歯科に通院，抜歯した

東京都千代田区開業

スタディーグループ 救歯会
既往はあるが継続的に治療した経験はない。同部位にフィ ステルを認め, 全顎的に著しい発赤, 腫脹, 動摇, 㐘牙の 位置移動が見られる。特に左上の 12 の動摇は顕著である (図 1).

\section{方法}

診断：慢性歯周炎広沉型

歯の動摇, 移動, 欠損による機能障害及び審美障害 治療経過：著明な炎症症状があり, 自然出血もみられるが カリエスは少なく, 歯周病に反応しやすいタイプと判断し た(図2、3)。レントゲン上 (図 4,5) で付着哀失が著し い1， 211,7 は早期に抜歯の予定とし，付着は少ないが 

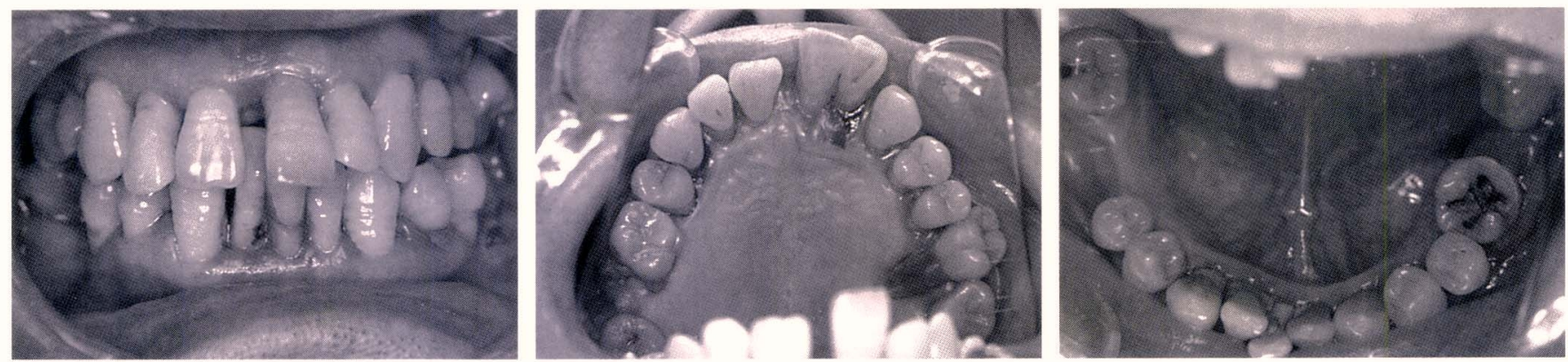

図 1995 年 8 月 崩壊の状態より，一大 図2，３上顎前歯部のフレアアウト，6 遠心根，6口蓋根の露出は著しい。下顎は欠損放置 決心して来院されたと思われる. のため, 歯牙の傾斜が著しい.

図4,5 $\overline{6 / 6}$ の欠損, 4 , 下顎前歯部の付着 の龯失が大きいことにより，若年期が歯周炎の 初発時期と推測される。
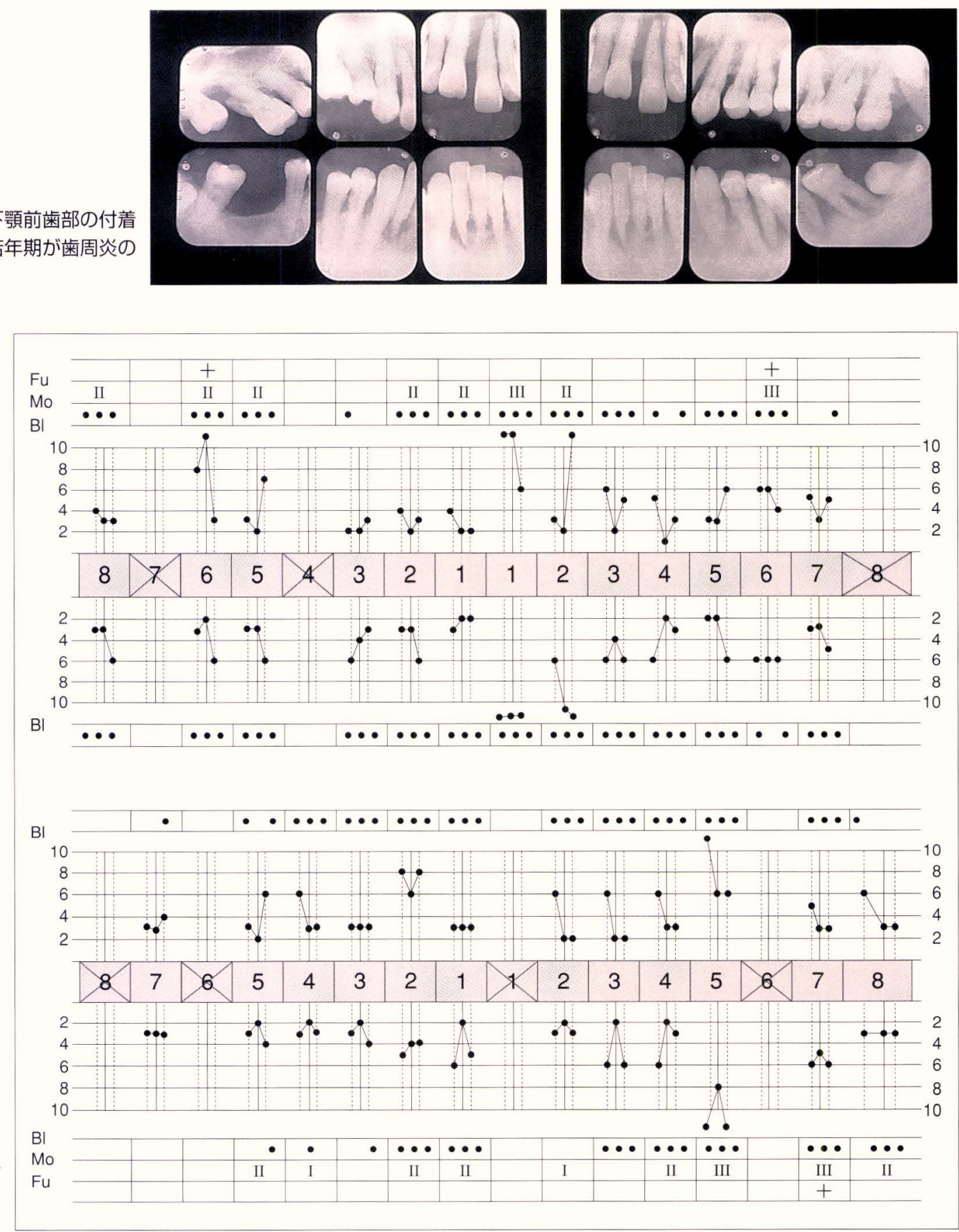
ビングチャート中央方向が 上顎口蓋側，下顎舌側となる 


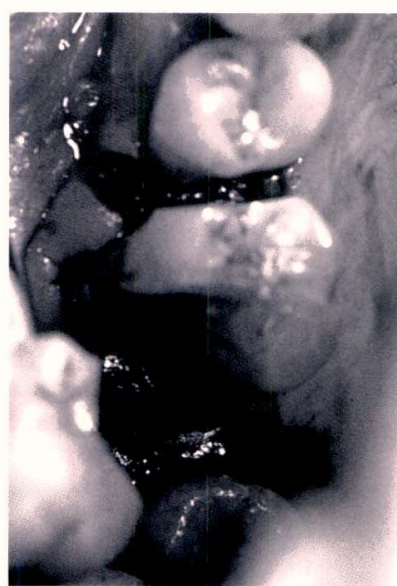

図 7 歯肉弁は根面へのアクセ 図 8 予想以上に付着量は少な スを目的とし最小限の剥離としい. た.

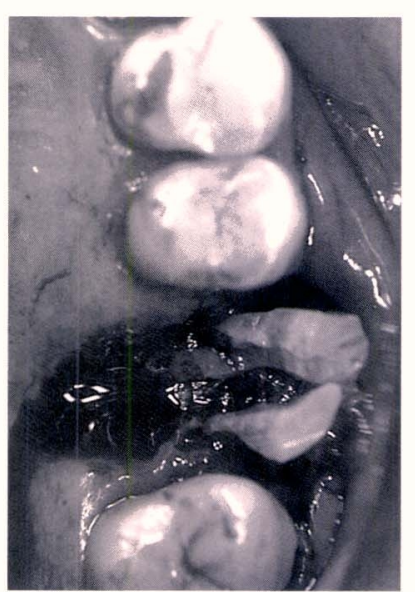



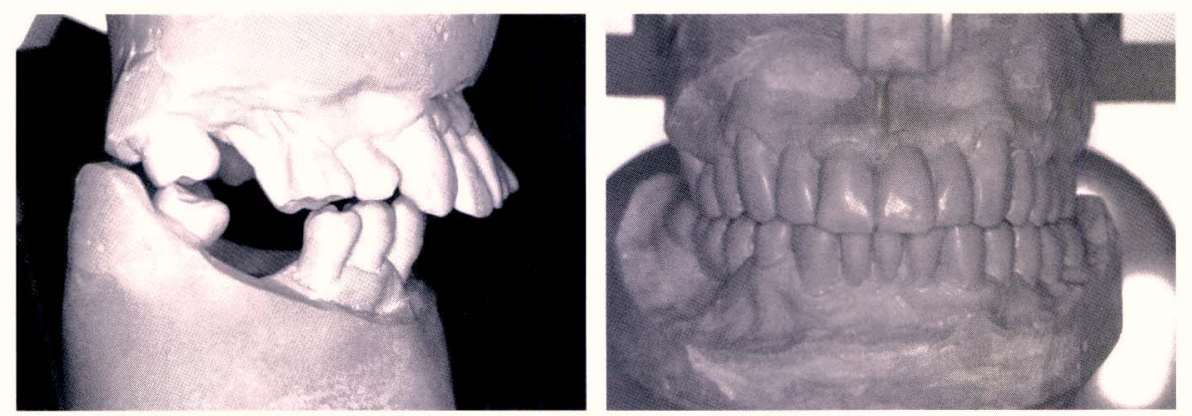

図 12 アングルロ級傾向，8 9 早期接触は咬 合調整を行った

図 13 中心位にてワックスアップを行い治療 のゴールを明確にした。
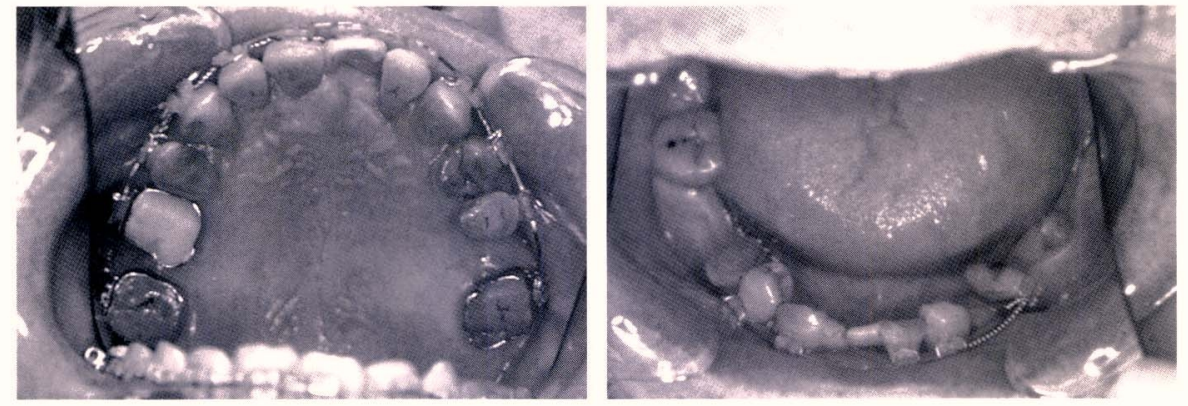

図 14，15 歯牙の垂直化，水平的な位置関 係の改善と同時に歯槽骨のレベリングも行 う. 2 2の廷出， 5 の根近接の改善も目的とし た.

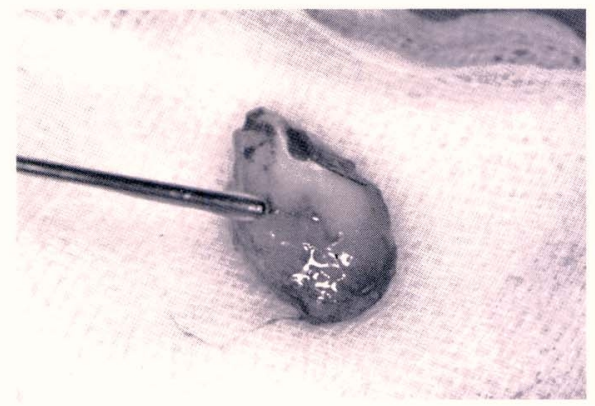

図 16 ジグリング後抜歯を行う, トリミング により露出した象牙質にエムドゲインを塗布し た.

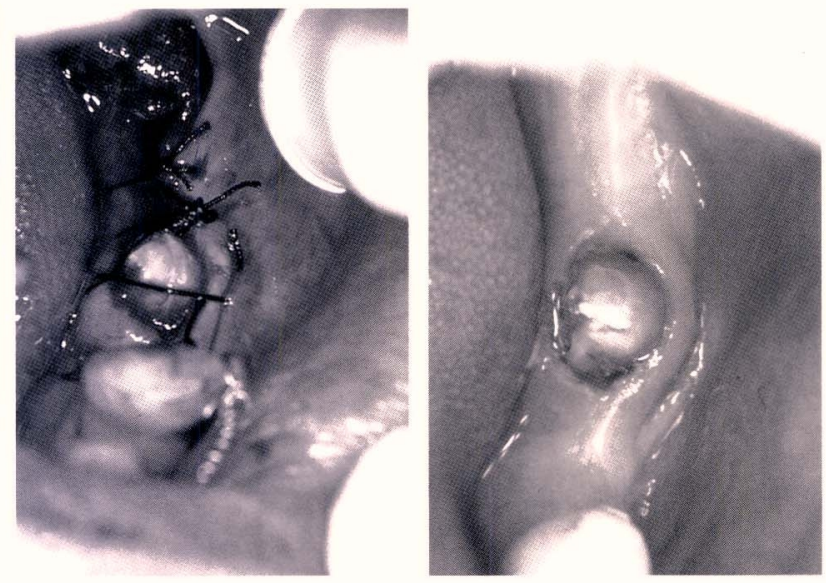

図 17 移植歯の固定は縫 合のみとした。

図 18 移植後 4 力月.

$6\rfloor,\lfloor 2,\lfloor 6, \sqrt{4}$ は保存疑問歯とし，初期治療の反応をみ て，保存か抜歯の判断をすることにした，図 6 に初診時 のプロービングチャートを示す. 可及的に歯の保存を試み，

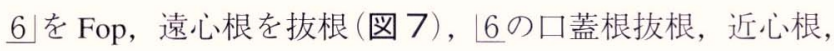
遠心根をルートセパレーション（図８）を行った。図 9, 10 に再評価時の状態を示す。

筆者は明確な抜歯の基準を持っていない。之れは年齢, 解剖学的な個体差, 治療に対する生体の反応, 1 口腔単位 で見た場合の歯牙の重要度は，歯牙の対合関係や補綴設計 により，全ての症例に扔いて違うと考えるからである，現 在行っている方法は保存疑問歯であっても必ず保存を試み 初期治療を行い，治療に対する組織の反応を確認し，テン ポラリークラウンで機能させ，その経過をみて最終判断を するようにしている.
この症例では 6 は右側の大曰歯部の咬合支持歯として重 要と判断し，最優先に保存を試みた。迆はテンポリークラ ウンをセットしたが，患者が不快感を訴えたため，後に抜 歯の判断となった。プロービングチャート(図１１）により， プロービングデプス, 出血点, 動摇度は著しく改善してお り，歯周組織の改善を確認した。安定した歯周組織のメン テナンス，咬合機能，審美性を獲得するには，tooth positionの改善が必要と判断した。

矯正治療を行うにあたり，中心位にて咬合器にス夕 ディーモデルを付着 (図 12) し, 診断用ワックスアップ

（図13）を行った。図14，15 に矯正治療中の状態を示 す，下顎左側の大鼠歯部に咬合支持歯がなく，患者からの 掑食障害の訴えもあり， 8 の 7 相当部への自家歯牙移植 を行った(図 16，17，18，19)。インプラントも選択 


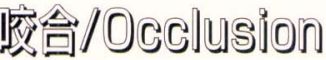
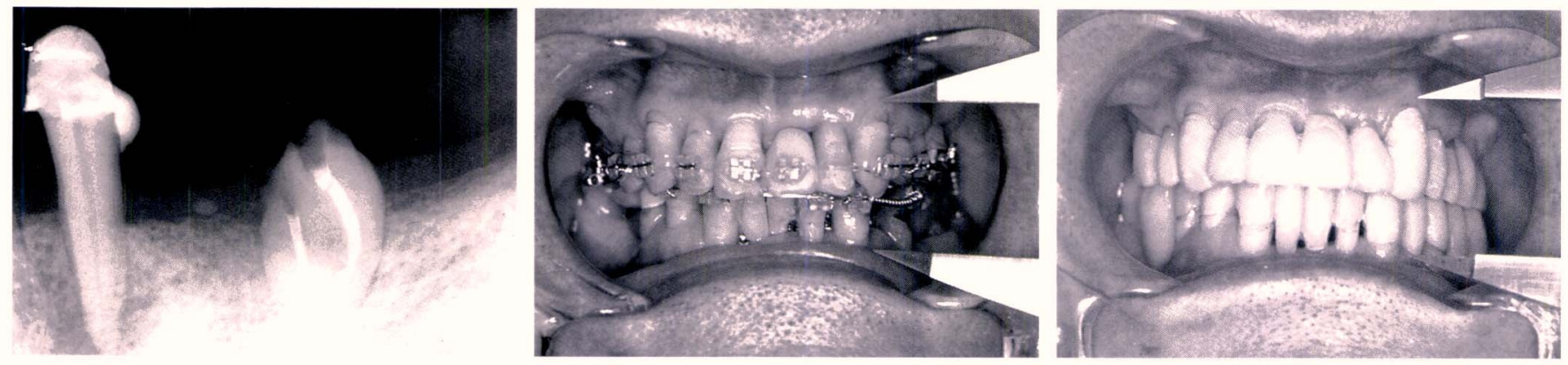

図 193 カ月間水酸化カルシウムにて貼薬 図 20，21歯牙の移動中，既存の咬合高径を保持するように考虑し，一，二次テンポラリー 後，根管充填を行う
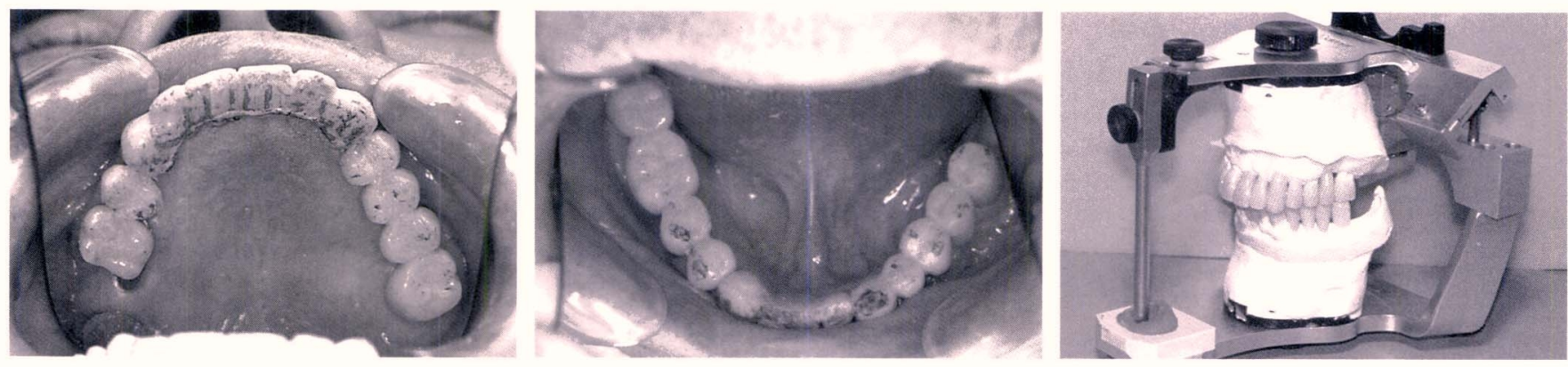

図22，23 口腔内で前方，側方運動を調整し，側方時運動時は犬歯誘導とした.

図 24 二次テンポラリークラウンの側方運動 記録をレジンにてガイドテーブルに移した.

図25,26 最終補緅物をイメージして製作 する。
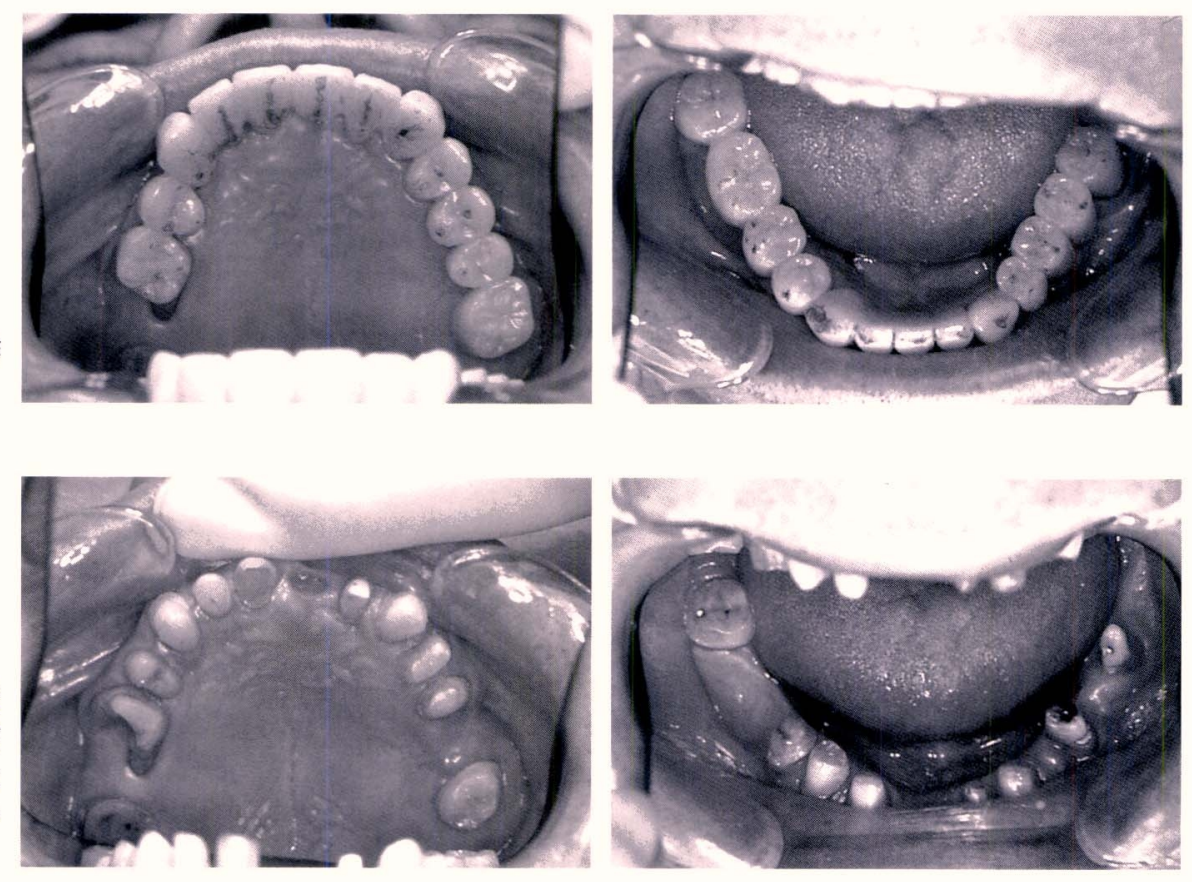

図27,28纪は審美性の獲得のためやむを 得す抜週を行う， 6 ，下顎移植歯以外は全て有 髄歯で形成，〈1部はオベイトポンティックと した．移植菌は歯折の要因を少なくするためし ジンコアとした.

肢の 1 つと考えたが, 対合歯である 7 へのダメージを考慮 し, この症例では天然歯同士の咬合接触を選択した。矯正 治療中は既存の咬合高径を保存するように配慮しながら行 い, テンポラリークラウンの参考とした(図20，21). 図 22, 23 に二次テンポラリークラウンの状態を示す. 口腔内で咬合調節した二次テンポラリーのアンテリアガイ
ダンスを咬合器上に移し, 三次テンポラリークラウンを作 成した (図 24). 図 25, 26 に三次テンポラリークラウ ンの状態を示す。顎関節, 歯周組織及び歯牙に臨床症状が ないことを確認した後, 最終印象を行った(図27,28).

咬合採得に関して, 筆者は以前, 徒手により中心位に誘 導して採得していたが, 現在では視覚で客観的に判断でき, 


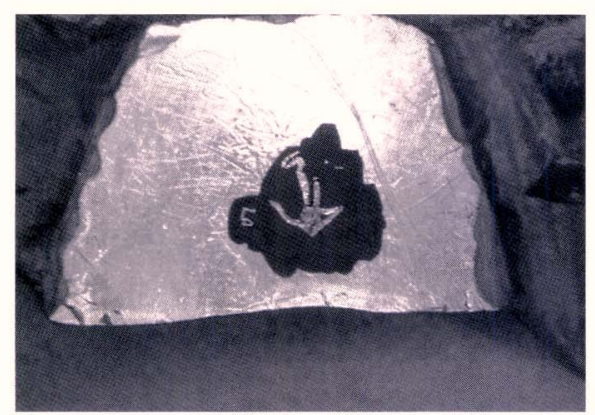

図 29 垂直的顎位はテンポラリークラウン, 水平的顎位は GoA のアペックスを採用した。
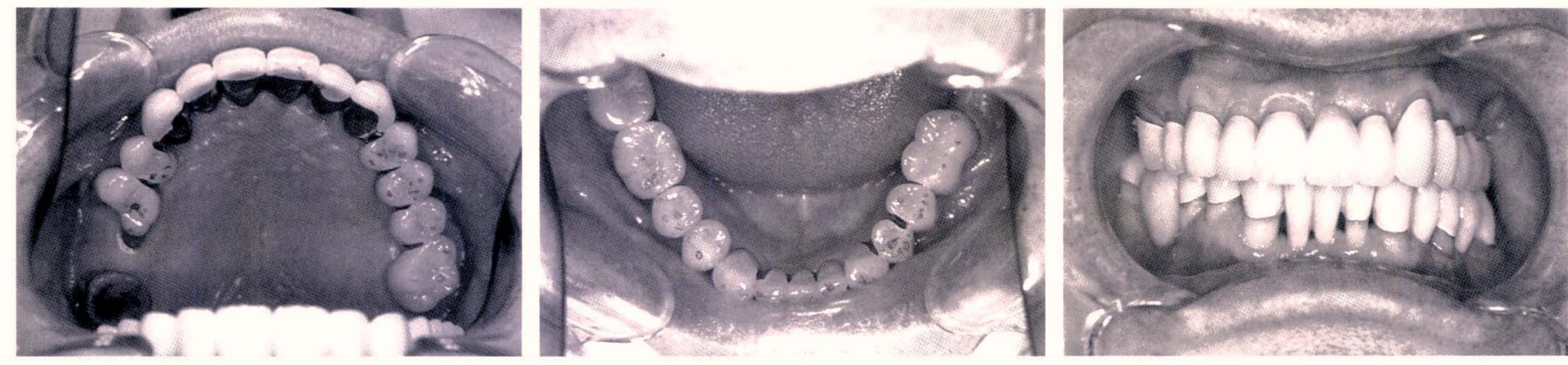

図 32, 33 患者の強い審美的要求で臼歯部はポーセレンオクルーザルとなった. 8 は咬合支 図 342000 年 4 月 初診時より 4 年半, 持とモチベーションの維持を目的とし保存した.
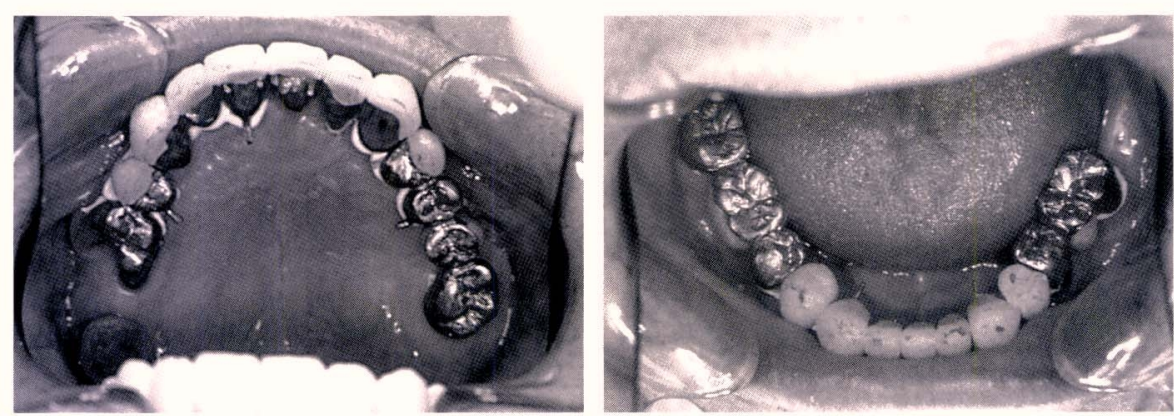

図30，31 3A の探針とフィットチェッカーにて適合状態を確認。当初の計画としては，百 歯部はメタルオクルーザルとした.

最終補緅物のマージンは歯肉緑上とした。

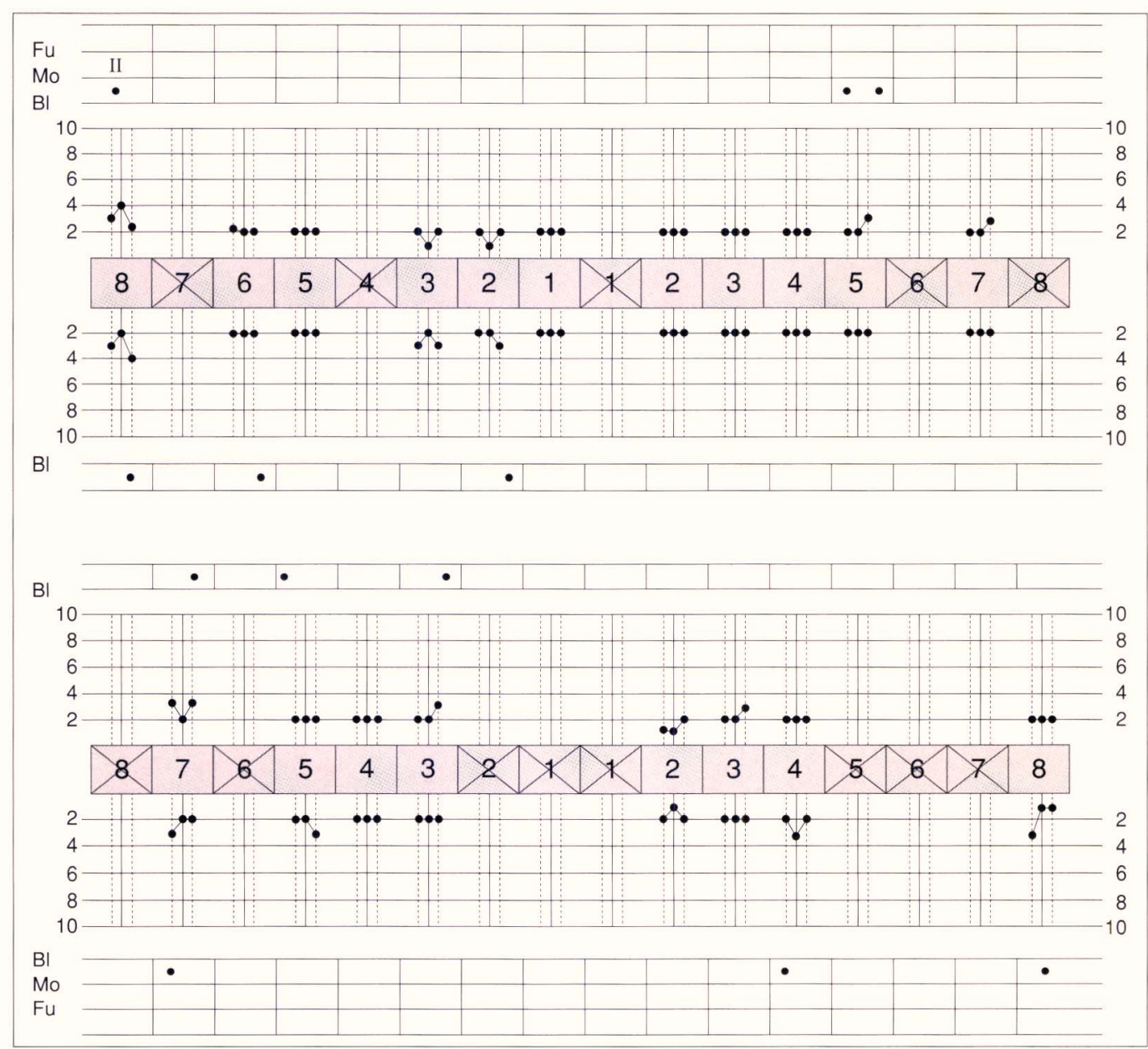

図352002年2月 最終 補緅より約 2 年。 


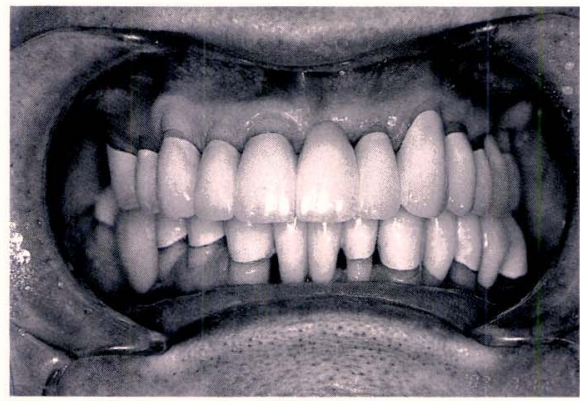

図 362003 年 7 月 メンテナンス時。最 終補緅より 3 年 3 カ月.
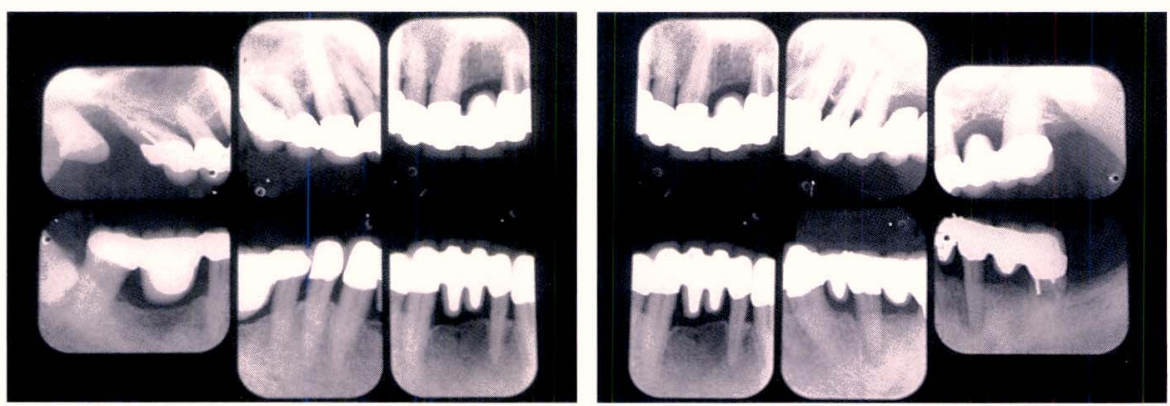

図 37, 38 最終補緅時, 歯槽硬線も明確に確認できる、 2 近心部の改善は著しい, 5 の根近 接も改善された、 4 根尖部に透過像を認めるが生活反応があるため経過観察とした. 6 近心に 付着の喪失を認める。
再現性も高いGoAを採用している(図29)。それにより， 咬合採得を行う術者の手技のばらつきを最小限にできると 考えている.メタル試適後, ビスケットベイクで再度試適 を行い(図30，31), 最終補綴物のセットを行った(図 32, 33，34). 現在 3〜 5 カ月の間隔でメンテナンスを 行っている(図 35, 36). 図 37, 38 に最終補綴時のデ ンタルを示す.

\section{考察}

治療計画立案時には, どの歯が保存可能なのかというこ とよりも，術者がどの歯を保存したいかということの方が 大きく関与しているように思う。筆者は, 保存疑問歯を最 初の時点で抜歯してしまった場合, 保存できる可能性の芽 を自ら摘んでしまったことで経過自体が存在しなくなって しまうと考える。この症例において， 6」， L2， $\sqrt{4}$ が初診 時の状態より 8 年あまり機能しているという意義は大きい と思う. 矯正治療による歯槽骨のレベリング, バーチカル ストップとなる臼歯部の咬合支持を両側に獲得できたこと も, 安定した経過につながるものと考えている. しかし逆 に，リスクのある歯牙をブリッジの支台歯に取りこんだこ とになり, 今後 6 , 左下移植歯の経過を注意深く追って行 くことが必要と思われる.

\section{謝辞}

稿を終えるにあたり, 人生の恩人である故渡辺皓司先生, 臨床見学の機会を与えて頂いた山崎長郎先生, 支台歯形成 を一から御指導頂いた西川義昌先生, 何時も貴重な御意見 を頂いている黒田昌彦先生, 富樫 潔先生, そして歯周治 療の主役である歯科衛生士の丸山咲に深謝の意を表しま क.

\section{参考文献}

1) アメリカ歯周病学会編, 岡田 宏訳：AAP 歯周治療法のコ ンセンサス，クインテッセンス出版 (東京), 1996.

2）茂野啓示, 西川義昌：一から学ぶ歯周外科の手技. 医歯薬 出版 (東京), 1997.

3) Birte Melsen 編, 花田晃治訳 : 現代矯正学のコンセンサス. クインテッセンス出版 (東京), 1993.

4）山崎長郎他：臨床歯周補綴 II マニュアル＆クリニック。第 一歯科出版 (東京), 1992.

5）黑田昌彦：コーヌスクローネ。医歯薬出版 (東京), 1984. 